\title{
AN INTRODUCTION TO A POSTMODERN APPROACH TO NURSING RESEARCH: DISCOURSE ANALYSIS - PART 1
}

\section{Laetitia Zeeman}

DCur (RAU)

Department of Nursing Science, Rand Afrikaans University

\author{
Marie Poggenpoel \\ $\mathrm{PhD}$ \\ Professor, Department of Nursing Science, Rand Afrikaans University \\ Corresponding author: mpo@edcur.rau.ac.za
}

\author{
Chris Myburgh \\ BSc (Hons), HED, MCom, DEd \\ Department Education Science, Rand Afrikaans University
}

Keywords: Discourse analysis; post modern; post structuralist; social constructionist

\begin{abstract}
This article serves as an introduction to discourse analysis. It therefore does not give an account for the whole research process. Due to logistical reasons, because this is a relatively new and multifaceted approach in research, this article involves only introductory remarks about discourse analysis as approach to qualitative, reflexive nursing research.

Different postmodern "approaches" to qualitative nursing research derived from other disciplines are being rooted in nursing as epistemology. Discourse analysis is introduced as a Poststructuralist and Social Constructionist "approach" to nursing research developing within the postmodern line of thought. A qualitative exploratory research design was chosen that explored specific Poststructuralist and Social Constructionist literature on research by means of an indepth literature review. The sample was chosen from Poststructuralist and Social Constructionist literature on research in general as these paradigms have not been described in South African literature on nursing research.

The ideas on discourse analysis as a research "approach" of Parker (1992:6-20) and Terre Blanche \& Durrheim (1999:154-167) are discussed. Discourse analysis could serve as a valuable "approach" in nursing research as it challenges current dominant ways of understanding or viewing the objects of study. This process opens up space for alternative reflections that could lead to change.
\end{abstract}

\section{ABSTRAK}

Hierdie artikel dien as ' $n$ inleiding tot diskoers-analise. Dit beoog dus nie om die hele navorsingsproses breedvoerig te bespreek nie aangesien diskoers-analise ' $n$ relatief nuwe en multifasettige benadering in navorsing is. Vanweë logistiese redes word in hierdie artikel slegs inleidende gedagtes oor diskoers-analise as benadering tot kwalitatiewe, refleksiewe verpleegnavorsing ingesluit.

Verskillende postmoderne "benaderings" tot kwalitatiewe navorsing word in die verpleegkunde as epistemologie beskryf en het begin wortelskiet. Diskoers-analise word bespreek as ' $n$ "benadering" tot navorsing wat ontstaan het uit die Poststrukturalisme en Sosiale konstruksionisme binne die postmoderne denkstroom. 'n Kwalitatiewe, eksplorerende navorsingsontwerp is gekies waardeur ' $n$ indiepte literatuurstudie onderneem is om diskoers-analise as "benadering" tot navorsing te ondersoek. Die literatuurstudie is op die paradigmas van Poststrukturalisme en Sosiale konstruksionisme gerig en die "benadering" tot navorsing wat uit hierdie paradigmas voortvloei aangesien hierdie raamwerke nog nie in Suid-Afrikaanse literatuur oor navorsing in die verpleegkunde vervat is nie. 
Die sienings oor diskoers-analise as "benadering" in navorsing van Parker (1992:6-20) en Terre Blanche \& Durrheim (1999:154-167) word bespreek. Diskoers-analise kan as ' $n$ waardevolle "benadering" tot navorsing in die verpleegkunde dien aangesien dit huidige dominante verstaanswyses bevraagteken. Dit skep ruimte vir alternatiewe refleksies en ander verstaansmoontlikhede waarbinne die potensiaal vir verandering dan ontstaan.

\section{INTRODUCTION}

Postmodernism is not a school of thought. It is not a unified intellectual movement with a definite goal or perspective. "Postmodernism can be the set of ideas which try to define or explain the state of affairs in society or a word used in many different contexts to cover many different aspects" (Ward, 1997:4). Postmodern theory sets about dismantling most of our normal ways of thinking about how meaning interpretation and reality works. This dismantling process is also visible in nursing and nursing research. Different postmodern "approaches" to nursing research derived from other disciplines are being rooted in nursing as an epistemology. Discourse analysis will be introduced as a Poststructuralist and Social Constructionist "approach" to nursing research developing from a postmodern line of thought.

The value of this research lies inter alia in the following: Postmodernism creates distance for the generation of alternatives in inter alia the culture, language, ways of thinking, stories and interpretations. The existence of alternative stories on one event, the existence of more than one interpretation of the world and the thought that the self has more than one view or part bring about big shifts and freedom.

Narrative therapy originated from the poststructuralistic way of thinking and the social constructivism. It works through the deconstruction of previous therapeutic models, therapeutic practices and dominant discourses that exist inside the culture group. The therapeutist and client/individual construct new insights and alternative stories or narratives during the therapeutic process. In the practice of narrative therapy the problem is seen as a problem. The person is not a problem. Any form of diagnosis or labeling are opposed because it sometimes happens that the individual becomes the diagnosis or label and this has a negative influence on the individual. In the practice of narrative therapy discourse analysis does not describe and explain the world. It does not make any claim on the truth, it is a reflexive process that is directed at change and progress.

\section{PROBLEM STATEMENT}

Discourse analysis has not widely been described in literature as a qualitative "approach" in nursing research. In South Africa this research "approach" is reasonably unfamiliar in nursing research. "Discourse analysis has its roots in linguistics, literary studies, and anthropology" (Ward, 1997:129). It is being practiced at present in virtually all of the humanities and the social sciences. Discourse analysis is an interdisciplinary research "approach" and can be of great worth if it is derived as Social Constructionist and Poststructuralist epistemology into nursing research.

Since this progress is unfamiliar in South Africa, certain key concepts will be discussed briefly:

Epistemology: Epistemology in this context refers to the changing forms of knowledge that arise from new conceptualisations of the world (Blackburn, 1994:123). Epistemology also refers to the study or theory of the nature and limits of experience, belief and knowledge (Allen, 2000:298)

Reflexivity: Social constructionism maintains that meanings are produced by a process of reflexivity. If we want to understand the meaning of 'shooting', for example, instead of representing an accurate picture of what is happening, we reflect on a set of actions from within a frame of reference (i.e. a discourse). Reflexivity is where the concept imbedded in a particular "form of life" makes available certain discourses, which lend meaning to objects and events (Durrheim, 1997:180).

Discourse: A discourse refers to: "... a more or less consistent set of ideas" (Monk, Winslade, Crocket \& Epston, 1996:30) or "a system of statements, practices, and institutional structures that share common values" (Hare-Mustin, 1994:19) and "...an interrelated system of statements which cohere around common meanings and values ...(that) are a product of social factors, of powers and practices, rather than an individual's set of ideas" 
(Hollway, 1983:231).

Paradigm structuralism: Structuralism can be traced back to the work of Ferdinand de Saussure. Structuralism searches out the patterns in any human production or texts. It assumes that the human mind is at the same time structured and a structuring agent. This process of structuring is, therefore a two-way street: humans, having shaped their world, are in turn shaped by it. Binary oppositions are the most fundamental relationships in language. They point to the deep structures, which carry the dominant discourses on which the text is based, and cannot be altered by rereading or reinterpreting the surface details of the narrative (Milne, 1989:21-23).

\section{PURPOSE OF THE STUDY}

The purpose of the study is to introduce a theoretical explanation of discourse analysis as a Poststructuralist and Social Constructionist "approach" to qualitative reflexive nursing research.

\section{METHOD}

A qualitative exploratory research design was chosen (De Vos, Strydom, Fouche, Poggenpoel \& Schurink, 1998:253; Mouton, 1996:102). It explored specific literature on research in other disciplines by means of an in-depth literature review or survey (Mouton, 1996:173). The sample was chosen from Poststructuralist and Social Constructionist literature on research in general as these paradigms have not been described in South African literature on nursing research.

\section{PARADIGM}

"Discourse analysis is a qualitative research design" (Terre Blanche \& Durrheim, 1999:48). It should first be situated in its broader paradigmatic context namely: Post structuralism and Social constructionism. "Post structuralism and Social constructionism developed within the postmodern line of thought" (Kvale, 1992:8). Certain central Structuralist ideas need to be highlighted before Post structuralism can be introduced.

\section{Structuralism}

"Structuralism is thought of as an approach or method rather than a clearly defined discipline" (Ward, 1997:80). The object of study in structuralist thought is the system and structure of language and how meaning is generated. To summarise: Structuralism asks where meaning comes from: "Does it come from the text itself? Does it come from the context in which the text is consumed: Is the reader free to create his or her own meaning? To what degree can the author of a text control how it is interpreted? Does the production of meaning arise from the interaction of these factors. If so, how do they interact?" (Ward, 1997:88)

Structuralist thought in research studies the deeper or underlying systems in language practices and how meaning is produced. "Structuralism and Post structuralism form much of the philosophical background of postmodern theory" (Ward, 1997:80). Within the Postmodern line of thought Post structuralism developed from the above mentioned central Structuralist ideas.

\section{Post structuralism}

Poststructuralist ideas received widespread attention with the work of Michel Foucault, Jacques Derrida and Barthes (Gavey, 1998:460). This line of thought is also informed by "post-Sassurean linguistics, Marxism (particularly Althusser's theory of ideology), feminism, the "new French feminists" (Kristeva, Cixous, Irigaray)" (Gavey, 1998:460; Ward, 1997:80-100).

In search of a definition for or a description of Post structuralism many problems are encountered. It is a virtually impossible process to define Post structuralism. At the center of post-structuralism is a resistance to any form of definition or identification "...presumably because such practices represent an attempt to pin down an essence which does not exist" (Gavey, 1998:119).

According to Foucault (1988:18) "...the premises of poststructuralism disallow any denominative, unified, or 'proper' definition of itself. Broadly it involves a critique of metaphysics: of the concepts of causality, of identity, of the subject, of power, knowledge and of truth".

Poststructuralist premises become clearer when its ideas on language and meaning in relation to Structuralist ideas are discussed. There is a difference between Structuralist and Poststructuralist's views on language and meaning. 
Ward $(1997: 92,100)$ explains that Structuralism sees language as a closed system and tries to fix individual texts to rigid linguistic frameworks whereby underlying meaning is exposed. Structuralism as mentioned, seeks the 'facts' about texts and the deeper, underlying, hidden fundamental structures that supports the texts. For Poststructuralists there are no facts (Ward, 1997:86104), there are only interpretations.

As Gergen (1991:10) argues, Poststructuralists try to open texts up and cut meaning loose. Poststructuralists do not necessarily believe that everything is meaningless, just that meaning is never factual or final. Post structuralism rejects the notion of ultimate, underlying grounds beneath meaning.

To Poststructuralist researchers language and language systems are important. One such a system operating through language described in Poststructuralist thought is discourse (Monk, Winslade, Crocket \& Epston 1996:30; Hare-Mustin, 1994:19; Hollway, 1983:231). Discourse can have many different meanings according to where it is used and by whom. "A discourse is an abstract public sphere of words and images" (Ward, 1997:129).

A discourse is not just an abstract concept; it exists in concrete social situations and has very real effects" (Terre Blanche \& Durrheim,1999:48-52). As example, a discourse relevant to nursing is the Biomedical discourse and its related discipline (nursing and the medical profession) and the relevant language spoken there, the institution (the academia related to it and the healthcare systems in South Africa) and the practice (the act of nursing, caring, healing).

In the discussion that follows discourse analysis will be introduced as a Poststructuralist and Social Constructionist "approach" to nursing research.

\section{Social constructionism}

Social constructionism studies how people interact with one another to construct modify and maintain what their society holds to be true, real and meaningful. Social constructionism maintains that meanings are produced by a process of reflexivity (Denzin \& Lincoln 1994:127, 128; Freedman \& Combs, 1996:22-28; Terre Blanche \&
Durrheim,1999:48).

Constructionism is concerned with broader patterns of social meaning encoded in language. According to Terre Blanche and Durrheim (1999:48) these premises leads to the following implications in research:

Social Constructionist methods want to show how understanding and experiences are derived from larger discourses. Social Constructionist approaches treat people as though their thoughts feelings and experiences were the products of systems of meaning that exist at a social rather than an individual level. Constructionism holds that human life-world is fundamentally constituted in language and that language should therefore be the object of study. Constructionists do not treat language as if it was neutral and transparent or as a route to underlying realities, rather language helps to construct reality.

Constructionism is concerned with broader patterns of social meaning encoded in language (Monk, et al. 1996:30; Hare-Mustin, 1994:19; Hollway, 1983:231). A discourse is a system with broader patterns of social meaning encoded in language that forms the object of study in Social Constructionist and Poststructuralist research. A short preface to discourse analysis, as a qualitative research design will ensue.

\section{DISCOURSE ANALYSIS}

Discourse analysis is not a descriptive and explanatory practice that aims at truth claims. It rather is a form of reflexive research. "Discourse analysts understand the task of research to be a reflexive and productive not a descriptive practice" (Parker, 1992:6).

\section{The aim of discourse analysis}

"Rather than describing and explaining the world and making truth claims, discourse analysis aims to account for how particular conceptions of the world become fixed and pass as truth" (Durrheim, 1997:181). "Seeing historically how effects of truth are produced in discourses which in themselves are neither true nor false" (Foucault, 1984:88).

Durrheim (1997:181) explains that discourse analysis 
is a reflexive process that aims to provide an account of how 'objects' in the world are constructed against a background of socially shared understanding. These socially shared understandings often have become institutionalised and gained factual status. It is a form of social critique.

"A social Constructionist epistemology moves away from the mechanistic and individualistic understanding of the object of study. It moves away from a conceptual critique to a social critique" (Durrheim, 1997:181). During discourse analysis we "want to understand the function of a particular discourse, the way they position their subjects in relations of contempt and respect, of domination and subordination or of opposition and resistance, we pass quickly and ineluctably from conceptual critique to social critique" (Parker, 1992:37). A concrete example of a discourse analysis as social critique is to be found in Part 2 of the article where a patriarchal discourse as example of a gender discourse is analysed. The analysis comments on the operation of a patriarchal discourse and on the gender dilemmas of women as its subjects.

Discourse analysis as described by Parker (1992:6) and Durrheim (1997:181) has a second goal: It is not only a reflexive process; it is also a productive process or a process that brings change. During discourse analysis reflexivity is employed to produce new meanings by showing how taken-for-granted everyday and scientific objects are embedded in certain 'regimes of truth'. During the reflexive process in research new meanings and ways of understanding the objects of research are generated. An example here can be seen in Part 2 of the article where it is argued that a patriarchal discourse might be destabilised by the work of alternative discourses (i.e. a discourse of single parenthood).

Some discourse analysts describe this second aim as the aim of overturning commonly accepted understandings of 'objects' by drawing on other marginalised discourses to demonstrate the constructed nature of common understandings. The following illustrates this: During the discourse analysis in Part 2 of the article the work of a patriarchal discourse is exposed. The analysis draws on alternative or marginalised discourses to demonstrate the constructed nature of gender and gender dilemmas.
In the words of Durrheim (1997:181): "What is the point of overturning convention and deconstructing truth? In short it has political aims of disrupting the oppressive and exploitative effects associated with institutionalized discourses and forms of life. Discourse analysis doesn't describe or explain the world; it is a critical enterprise, a reflexive process, a form of ideology critique".

Discourse analysis ".. does not aspire to truth, but to change" (Durrheim, 1997:181). Foucault (1984:88) said: "Knowledge is not made for understanding; it is made for cutting". To do a discourse analysis is to exercise the cutting tool of knowledge toward the aims of human emancipation.

\section{DISCUSSION}

\section{The "how" of discourse analysis}

Discourses are not discreet entities, but are intertwined with each other and constantly changing. Therefore it is virtually impossible to pin down a discourse. Constructionist researchers study discourses as if they are living entities. "Discourses live in texts" (Terre Blanche \& Durrheim, 1999:154-167). Books, articles, advertisements, movies, transcribed interviews serve as examples of texts. Discourses as objects are studied by examining them in texts. The researcher in nursing science may choose any of these mediums as texts. For example transcribed interviews serve as texts where discourses may be found at work. The texts are examined during the analysis of a discourse.

There is no field guide to discourse analysis. "Even though researchers, students and teachers of discursive approaches have to set out a method, there is really no method as such, there is no one thing called discourse analysis. Discourse analysis is not a set of methodological techniques that only carefully trained experts understand and are able to use..." (Parker, Levett, Kottler \& Burman, 1997:198).

The ideas on discourse analysis as a research 'approach' of Parker (1992:6-20) and Terre Blanche \& Durrheim (1999:154-167) are introduced. These ideas do not constitute a method, and they should not be followed sequentially (Parker, 1992:6-20; Terre Blanche \& Durrheim, 1999:154-167). They serve as mere pointers 
in directing analyses.

Terre Blanche \& Durrheim's (1999:154-167) three-facet 'approach' to discourse analysis:

\section{Discourses}

Discourses manifest in texts. Texts become intelligible by drawing on discourses.

Discourses can be identified using cultural competence and critical distance.

'Tricks':

- look for binary oppositions,

- identify recurrent terms, phrases and metaphors,

- identify subjects that include the author and listener.

\section{Effects}

- Not 'what does the text say?', but 'what does the text do?'

- Both explicit and implicit intentions of a text

- Why? (these oppositions, these recurrent terms, these subjects)

- What? (other elements could have been used)

. How? (are the effects achieved)

\section{Contexts}

- Show patterns of variation and consistency of discourses across texts

- The micro-context of conversation and debate

- $\quad$ Other texts and discourses

. The institutional, ideological and historical context

- The analyst (and the dangers of idealism and relativism)

The abovementioned 'method' of Terre Blanche \& Durrheim can be combined with the following 'approach' of Parker.

Parker's (1992:6-20) 'approach' to discourse analysis: Discourse lives in texts: Considers everything to be text and explores the connotations, allusions and implications that the text evokes. A discourse is about objects: Discourses are practices that systematically form the objects of which they speak. A discourse is about objects, and discourse analysis is about discourses as objects. Ask the question: "what objects are referred to?", and describe them. Talk about the talk as if it were an object, a discourse. A discourse contains subjects: Specify what types of persons are talked about and speculate what rights they have to speak.

- A discourse is a system of meanings: 'Map' a picture of the world this discourse represents. Work out how a text using this discourse would deal with objections.

- A discourse refers to other discourses: Set different discourses against each other and see what objects they form. Identify points where they overlap.

- A discourse reflects on its own way of speaking: Refer to other texts to elaborate the discourse. Reflect on the term used to describe the discourse.

- Discourses are historically located: Look at how and where the discourses emerged and describe how they have changed.

- Discourses support institutions: Identify institutions that are reinforced when this discourse is used, and identify the institutions that are subverted when this discourse appears. Discourses reproduce power relations: Identify which categories of persons gain and lose from implying the discourse. Identify who would want to promote or dissolve the discourse.

Discourses have ideological effects: Show how a discourse connects with other discourses, which sanction oppression and how dominant groups prevent those who use subjugated discourses from 'making history'.

As mentioned these ideas do not form a specific methodology for discourse analysis. They do not constitute a technique or a method and should not be followed successively. They serve as mere pointers in directing analyses.

\section{CONCLUSION}

Discourse analysis was briefly introduced as a Postmodern 'approach' to nursing research. The paradigmatic foundation for discourse analysis as mentioned is rooted within Post structuralism and Social Constructionism that developed within the postmodern line of thought. 
Discourse analysis could serve as a valuable "approach" in nursing research as it challenges current dominant ways of understanding or viewing the objects of study. This process opens up space for alternative reflections that could lead to change.

Part 2 serves as an example of a form of discourse analysis (Zeeman, 2000:65-143).

\section{LIST OF REFERENCES}

ALLEN, R 2000: The new Penguin English dictionary. Penguin Group: London.

BLACKBURN, S 1994: Oxford dictionary of philosophy. Oxford University Press: Oxford.

DENZIN, NK \& LINCOLN, YS 1994: Handbook of qualitative research. Thousand Oaks: Sage.

DE VOS, AS; STRYDOM, H; FOUCHE, CB; POGGENPOEL, M \& SCHURINK, W 1998: Research at grass roots. A primer for the caring professions. Pretoria: JL van Schaik Academic.

DURRHEIM, K 1997: Social constructionism, discourse and psychology. South African Journal of Psychology, 27(3):175-182. FOUCAULT, M 1984: Nietzsche, genealogy, history. (In: Rainbow, $P$ ed. 1984: The Foucault reader. Harmondsworth: Penguin, pp 76100.)

FOUCAULT, M 1988: Politics, philosophy, culture: Interviews and other writings 1977-1984. London: Chapman \& Hall.

FREEDMAN, J \& COMBS, G 1996: Narrative therapy. The social construction of preferred realities. Illinois: Evanston Family Therapy Center.

GAVEY, N 1998: Feminist Post structuralism and discourse analysis: Contributions to feminist psychology. Psychology of Women Quarterly, 13:459-475.

GERGEN, KJ 1991: The saturated self. Dilemmas of identity in contemporary life. USA: Basic Books.

HARE-MUSTIN, R 1994: Discourses in the mirrored room: A postmodern analysis of therapy. Family Process, 33:19-35.

HOLLWAY, W 1983: Heterosexual sex: Power and desire for the other - sex and love: new thoughts on old contradictions. London: The Women's Press.

KVALE, S 1992: Psychology and postmodernism. London: Sage. MILNE, P 1989: Realism, deconstruction and the feminist standpoint. Journal for the Theory of Social Behaviour, 28(4):349-372. MONK, G; WINSLADE, J; CROCKET, K \& EPSTON, D 1996: Narrative therapy in practice. The archeaology of hope. San Francisco: Jossey-Bass.
MOUTON, J 1996: Understanding social research. Pretoria: JL van Schaik.

PARKER, I 1992: Discourse dynamics: Critical analysis for social and individual psychology. London: Routledge.

PARKER, I; LEVETT, A; KOTTLER, A \& BURMAN, E 1997: Culture, power and difference: Discourse analysis in South Africa. London: Zen Books.

TERRE BLANCHE, MJ \& DURRHEIM, K 1999: Research in practice: applied methods for the social sciences. Cape Town: University of Cape Town Press.

WARD, G 1997: Postmodernism. Illinois: Teach Yourself Books.

ZEEMAN, L 2000: 'n Diskoers-analise: Unieke vroue leef te midde van die werking van 'n patriargale diskoers. Johannesburg: Rand Afrikaans University (D.Cur Thesis). 